\title{
Molecular and morphological traits of Pyricularia oryzae Cav. in the south of Russia
}

\author{
Elena Dubina ${ }^{1,2,{ }^{*}, \text { Dmitry Nartymov }}{ }^{1}$, Margarita Ruban ${ }^{1}$, and Yuliya Aniskina ${ }^{3}$ \\ ${ }^{1}$ Federal Scientific Rice Centre, 350921, Belozerny, 3, Krasnodar, Russian Federation \\ ${ }^{2}$ Kuban State Agrarian University named after I.T. Trubilin, 350004, Kalinina, 13, Krasnodar, \\ Russian Federation \\ ${ }^{3}$ All-Russian Research Institute of Agricultural Biotechnology, 127550, 42, st. Timiryazevskaya, \\ Moscow, Russian Federation
}

\begin{abstract}
Based on molecular genetic approaches, a study of the biodiversity of the phytopathogenic fungus Pyricularia oryzae Cav. was carried out in the south of Russia, the classification of morphological and cultural traits of the pathogen was carried out. In 2020, monitoring was carried out and 9 strains of the pathogen were isolated from the affected herbarium material collected from the fields of five ecological ricegrowing zones of Krasnodar region (Krasnoarmeisky, Kalininsky, Abinsky, Slavyansky districts, Krasnodar). Using a multiplex PCR system based on fragment analysis, among the studied strains of Pyricularia oryzae Cav. 5 genotypes were identified in 2020, each of which is was characterized by a unique genetic profile. Their «DNA-passports» have been compiled. The studied isolates of the blast pathogen were characterized by morphological and cultural traits. 6 morphotypes of the pathogen were identified. Classification of the pathogen by morphological, cultural and genetic traits will allow obtaining scientifically grounded and comparable data that can be used in the analysis of the interaction of blast strains with rice plants on different varieties and in different agrotechnological conditions in order to improve and rationalize agricultural activities. In addition, the studied approaches open up the possibility of using data in breeding, allowing the identification of pathogen forms that infect certain varieties.
\end{abstract}

\section{Introduction}

Study of genetic structure and biological diversity of highly variable fungi phytopathogens as well as identification of effective resistance genes of cultivated plants to diseases remain an urgent problem. $[1,2,3]$.

According to the degree of harmfulness for rice, blast disease (the causative agent - the imperfect fungus Pyricularia oryzae Cav. (Magnaporthe grisea (Herbert) Barr)) takes the first place. The World Institute of Mycology has registered this disease in more than 80 countries, and in recent years, a high severity of this disease has been noted in all ricegrowing regions of the world $[2,4,5]$.

\footnotetext{
*Corresponding author: lenakrug1@rambler.ru
} 
P. oryzae Cav. pathogen affects all aboveground plant organs and is dangerous during the entire rice growing season. Small caryopses develop on the affected plants, the setting of seeds in the panicle decreases, the grain yield lowers to $40 \%$, and the quality of products deteriorates sharply. In the presence of favorable conditions, the blast pathogen may reduce the rice yield by up to $45 \%$, and in the years of epiphytotic yield damage can reach $100 \%$ [6-8].

Breeding for resistance to phytopathogenic fungi is more difficult than breeding for any other economically valuable trait. This difficulty is determined by the race-forming processes continuously going on in the pathogen. With a change in the cultivated assortment of rice, a strict selection takes place for the survival of the P. oryzae pathogen itself, as a result of which new races, pathotypes of the blast pathogen appear $[6,8]$. To conduct successful breeding for resistance to this disease, it is necessary to have a clear understanding of the evolution of the pathogen; knowing its intrapopulation structure, virulence gene pool and interaction features in the host-parasite system; constantly conducting a wide search for new sources of resistance and creating a bank of resistance genes and pathogen strains. These studies are essential for understanding what the $\mathrm{P}$. oryzae pathogen is at the present stage. Only on the basis of all this information the correct approach to the selection of resistance types and the most effective method for developing resistant genetic resources to the disease can be developed.

Purpose of the work: to study the genetic diversity of $P$. oryzae pathogen strains by DNA polymorphism and morphological and cultural characteristics of the south of Russia.

Research tasks:

1. To characterize the biodiversity of $\mathrm{P}$. oryzae by morphological and cultural traits.

2. To conduct genetic certification of pathogen field strains using PCR (microsatellite) markers based on fragment analysis.

3. To draw up their "DNA-passports".

4. To organize the results obtained in the database [19].

5. To determine effective genes for resistance to blast disease, as well as genes for virulence of Pyricularia oryzae Cav. pathogen.

In the future it will allow to carry out a comparative characterization of the microsatellite profile of each newly isolated field strain of the pathogen with those from the database [19], thus assessing the degree of their genetic similarity or difference, as well as to control the variability of the pathogen by determining the so-called "lines" or "pathotypes" of a pathogen.

The implementation of the obtained results will lay the foundations for solving the problem of zonal distribution of rice varieties in the south of Russia, that will reduce crop yield losses and increase the socio-economic development of the rice growing industry.

\section{Methods}

To study the genetic diversity of the blast pathogen by molecular genetic methods, the fungus DNA was isolated from a mixture of mycelium and conidia of the monoconidial culture Pyricularia oryzae Cav. by the CTAB method [9]. The method consists in using hexadecyltrimethylammonium bromide as a detergent in lysis buffer.

The composition of the lysis CTAB buffer: $0.2 \mathrm{M}$ Tris pH 8; $2 \mathrm{M} \mathrm{NaCl}$; $0.05 \mathrm{M}$ EDTA; $2 \%$ CTAB.

The growth of the mycelium for DNA isolation was carried out in Petri dishes on liquid carrot agar medium. When the required biomass was reached, the mycelium was removed from the dishes and grounded in $700 \mu \mathrm{L}$ of lysis CTAB buffer in a sterile ceramic mortar. Then the resulting mixture was transferred to an Eppendorf tube and incubated at $65^{\circ} \mathrm{C}$ for an hour. To the resulting mixture, $500 \mu \mathrm{L}$ of chloroform were added and centrifuged for 10 
min. at $13,000 \mathrm{rpm}$ Then, using a pipetman, $500 \mu \mathrm{L}$ of the supernatant liquid were taken with a $1000 \mu \mathrm{L}$ pipetman, another $500 \mu \mathrm{L}$ of chloroform were added to it, and centrifugation was repeated. To the obtained supernatant, $400 \mu \mathrm{l}$ of isopropanol were added and the solution was placed in a freezer for 2 hours. After it was centrifuged for $10 \mathrm{~min}$ at $13,000 \mathrm{rpm}$. The formed DNA precipitate was washed with cooled $70 \%$ ethanol and resuspended in $50 \mu \mathrm{l}$ of buffer TE for storage at $-20^{\circ} \mathrm{C}$.

DNA amplification of the phytopathogenic fungus Pyricularia oryzae Cav. was carried out in a volume of $25 \mu$ containing 1 PCR-buffer, 1.25 units of Taq DNA-polymerase, 100 $\mu \mathrm{mol}$ of dNTP (DNA-Technology llc, Russia), 10 pmol of each primer, and $5 \mu 1$ of DNA solution in a detecting thermal cycler (CFX-BioRad, USA) according to the program: $950 \mathrm{C}$ $-10 \mathrm{~min},\left(94{ }^{\circ} \mathrm{C}-30 \mathrm{~s}, 55^{\circ} \mathrm{C}-30 \mathrm{~s}, 72^{\circ} \mathrm{C}-30 \mathrm{~s}\right) 30$ cycles and final elongation $-72{ }^{\circ} \mathrm{C}$ 5 min.

Sequence of SSR-markers used in the study is presented in Table $1[10,11]$.

Table 1. Microsatellite markers used for studying biodiversity of blast agent.

\begin{tabular}{|c|c|c|c|c|c|c|c|c|}
\hline $\begin{array}{c}\text { Mar } \\
\text { ker } \\
\text { nam } \\
\text { e }\end{array}$ & Origin & $\begin{array}{c}\text { Chro } \\
\text { mo } \\
\text { some } \\
\text { (geno } \\
\text { me } \\
\text { conti } \\
\text { g) }\end{array}$ & $\begin{array}{c}\text { Refere } \\
\text { nce } \\
\text { for } \\
\text { genomi } \\
\text { c } \\
\text { sequen } \\
\text { ce }\end{array}$ & $\begin{array}{c}\text { Repe } \\
\text { at } \\
\text { motif }\end{array}$ & Primers & $\begin{array}{c}\text { Ta } \\
\left({ }^{\circ} \mathbf{C}\right)\end{array}$ & $\begin{array}{c}\text { Multi } \\
\text { plex } \\
\text { pool }\end{array}$ & $\begin{array}{c}\text { Allele } \\
\text { size } \\
\text { range, } \\
\text { bp }\end{array}$ \\
\hline $\begin{array}{c}\text { pyrms } \\
07-08\end{array}$ & $\begin{array}{l}\text { Sequenc } \\
\text { ed BAC }\end{array}$ & $\begin{array}{c}7 \\
(557)\end{array}$ & $\begin{array}{l}\text { Kaye } \\
\text { et al. } \\
2003\end{array}$ & $\begin{array}{c}\text { CT/ } \\
\text { GA29 }\end{array}$ & $\begin{array}{c}\text { F: (NED)- } \\
\text { GCAAATA } \\
\text { ACAGGAA } \\
\text { AACG } \\
\text { R: } \\
\text { AGAAAGA } \\
\text { GAC } \\
\text { AAAACAC } \\
\text { TGG }\end{array}$ & 55 & 1 & $116 / 162$ \\
\hline $\begin{array}{l}\text { pyrms } \\
43-44\end{array}$ & $\begin{array}{l}\text { BAC } \\
\text { end }\end{array}$ & $\begin{array}{c}4 \\
(864)\end{array}$ & $\begin{array}{l}\text { Kaye } \\
\text { et al. } \\
2003\end{array}$ & TA12 & $\begin{array}{c}\text { F:(FAM)- } \\
\text { CAGTAGG } \\
\text { CTTGGAA } \\
\text { TTGA } \\
\text { AAAA } \\
\text { R: } \\
\text { CTTGATT } \\
\text { GGTG } \\
\text { GTGGTGT } \\
\text { TG } \\
\end{array}$ & 55 & 2 & $205 / 233$ \\
\hline $\begin{array}{l}\text { pyrms } \\
47-48\end{array}$ & $\begin{array}{c}\text { BAC } \\
\text { end }\end{array}$ & $\begin{array}{c}4 \\
(781)\end{array}$ & $\begin{array}{l}\text { Kaye } \\
\text { et al. } \\
2003\end{array}$ & TA15 & $\begin{array}{c}\text { F: (HEX)- } \\
\text { TCACATT } \\
\text { TGCTTGC } \\
\text { TGGAGT } \\
\text { R:AGACA } \\
\text { GGGTTGA } \\
\text { CGGCTAA } \\
\text { A } \\
\end{array}$ & 55 & 2 & $164 / 196$ \\
\hline $\begin{array}{l}\text { pyrms } \\
83-84\end{array}$ & $\begin{array}{l}\text { BAC } \\
\text { end }\end{array}$ & $\begin{array}{c}2 \\
(1895)\end{array}$ & $\begin{array}{l}\text { Kaye } \\
\text { et al. } \\
2003\end{array}$ & $\begin{array}{c}\text { TCA/ } \\
\text { AGT1 } \\
3\end{array}$ & $\begin{array}{c}\text { F:(FAM)- } \\
\text { GTCTGCC } \\
\text { TCGACTC } \\
\text { CTTCAC } \\
\text { R: }\end{array}$ & 55 & 2 & $168 / 189$ \\
\hline
\end{tabular}




\begin{tabular}{|c|c|c|c|c|c|c|c|c|}
\hline & & & & & $\begin{array}{c}\text { AGCCCAA } \\
\text { AAACA } \\
\text { GAAAGCA } \\
\text { A }\end{array}$ & & & \\
\hline $\begin{array}{c}\text { pyrms } \\
99- \\
100\end{array}$ & $\begin{array}{c}\text { BAC } \\
\text { end }\end{array}$ & $\begin{array}{c}5 \\
(718)\end{array}$ & $\begin{array}{l}\text { Kaye } \\
\text { et al. } \\
2003\end{array}$ & $\begin{array}{c}\mathrm{ACC} / \\
\mathrm{TGG} 2 \\
0\end{array}$ & $\begin{array}{c}\text { F: (NED)- } \\
\text { CACCACT } \\
\text { TTATGGC } \\
\text { GCAGT } \\
\text { R: } \\
\text { ACCTAGG } \\
\text { TAGG } \\
\text { TATACAT } \\
\text { GTTGTT }\end{array}$ & 55 & 2 & $178 / 222$ \\
\hline $\begin{array}{c}\text { pyrms } \\
427- \\
428\end{array}$ & $\begin{array}{c}\text { Genome } \\
\text { sequenc } \\
\mathrm{e}\end{array}$ & $\begin{array}{c}5 \\
(718)\end{array}$ & $\begin{array}{l}\text { Dean } \\
\text { et al. } \\
2005\end{array}$ & $\begin{array}{c}\text { AT/ } \\
\text { TA16 }\end{array}$ & $\begin{array}{c}\text { F:(HEX)- } \\
\text { CTGTCAC } \\
\text { CACAACC } \\
\text { AAGACG } \\
\text { R: } \\
\text { TTGCCCT } \\
\text { GATTT } \\
\text { GTCAGTC } \\
\text { A }\end{array}$ & 55 & 2 & $212 / 220$ \\
\hline
\end{tabular}

Fragment analysis was carried out for visualization of PCR products on an automatic genetic analyzer "NANOPHOR-05" (Institute of Analytical Instrumentation, Russia) with the support of Research Equipment Sharing Center "Biotechnology" of All-Russian Research Institute of Agricultural Biotechnology.

Data processing is performed using GeneMapper software.

The fungus culture was isolated from diseased rice tissues (stem nodes, leaves, panicle parts) collected from rice fields, in accordance with the guidelines developed at the AllRussian Research Institute of Phytopathology [12]. Samples of the affected tissue were washed with sterile water and placed on sterile carrot-sugar agar medium in Petri dishes, which were then placed in a humid $(100 \%)$ chamber at a temperature of $27 \pm 1^{\circ} \mathrm{C}$, which was optimal for the formation of conidia of the fungus Pyricularia oryzae Cav. The resulting pure culture was cultivated in a thermostat until the fungal colony was distributed over the entire surface of the agar medium, then the selected isolates were described by morphological and cultural traits [13-16].

\section{Results}

\subsection{Studing biodiversity of Pyricularia oryzae Cav. on the basis of microbiology methods in the South of Russia}

Recently, the growing distribution and harmfulness of the phytopathogenic fungus Pyricularia oryzae Cav have been observed in the rice-growing regions of Russia. Therefore, the question of studying the genetic structure, determining the pathotype of the local population of $\mathrm{P}$. oryzae is very relevant, especially for the main rice-producing region of Russia - Krasnodar region [17, 18].

Such knowledge is of particular interest, since it makes it possible to predict the emergence of new P. oryzae races and pathotypes, and is also a necessary theoretical basis for development of genetic sources with long-term blast resistance. [19, 20$]$.

For this purpose, we annually conduct monitoring (survey) of rice-growing farms in the south of Russia for the damage of rice crops by blast. In 2020, 10 rice growing farms were 
surveyed in five ecological zones of Krasnodar region (Krasnoarmeisky, Abinsky, Slavyansky, Kalininsky districts and the city of Krasnodar). Herbarium material with traits of disease was collected. Nine strains of Pyricularia oryzae Cav with different sporulating ability were isolated from the affected leaves, stem nodes, and panicles of rice plants. All obtained P. oryzae strains have a unique morphotype.

Tables 2, 3 show their origin and description by morphological and cultural traits (the nature of the colony growth, the color of the upper mycelium and spores, the color of the lower mycelium) [22].

Table 2. Origin of Pyricularia oryzae Cav. strains, 2020.

\begin{tabular}{|c|c|c|c|c|c|}
\hline № & $\begin{array}{c}\text { Strain } \\
\text { number }\end{array}$ & District & Selection date & Variety & Part of plant \\
\hline 1 & 1.20 & Krasnoarmeisky & 06.07 & Cahika & leaf \\
\hline 2 & 5.20 & Krasnoarmeisky & 15.07. & Favorit & leaf \\
\hline 3 & 7.20 & Krasnoarmeisky & 15.07. & Polevik & leaf \\
\hline 4 & 10.20 & Krasnoarmeisky & 20.07 & Rapan & leaf \\
\hline 5 & 11.20 & Kalininsky & 21.07 & Istok & leaf \\
\hline 6 & 12.20 & Krasnoarmeisky & 22.07 & Istok & leaf \\
\hline 7 & 13.20 & Krasnoarmeisky & 22.07 & Istok & leaf \\
\hline 8 & 16.20 & Slavyansky & 12.08 & Rapan & panicle stalk \\
\hline 9 & 20.20 & Krasnodar, FSBSI "FSRC" & 21.08 & KP-20 & node \\
\hline
\end{tabular}

Table 3. Morphological and cultural traits of P. oryzae Cav. strains, 2020.

\begin{tabular}{|c|c|c|l|c|c|c|}
\hline No & $\begin{array}{c}\text { Growth } \\
\text { pattern }\end{array}$ & $\begin{array}{c}\text { Structur } \\
\text { e }\end{array}$ & Relief & Profile & $\begin{array}{c}\text { Mycelium } \\
\text { color }\end{array}$ & $\begin{array}{c}\text { Substract } \\
\text { color }\end{array}$ \\
\hline 1.20 & Multidirectional & Flocky & Conical & Low & Typical & Brown \\
\hline 5.20 & Zoned & Flocky & Nodular & Low & Light & Black \\
\hline 7.20 & Unidirectional & Felted & Conical & Medium & Olive & Black \\
\hline 10.20 & Unidirectional & Felted & Conical & Medium & Olive & Black \\
\hline 11.20 & Zoned & Flocky & Nodular & Low & Light & Black \\
\hline 12.20 & Unidirectional & Felted & Uniform & Low & Typical & Gray \\
\hline 13.20 & Zoned & Flocky & Nodular & Low & Light & Black \\
\hline 16.20 & Concentric & Felted & Conical & Medium & Olive & Black \\
\hline 20.20 & Zoned & Flocky & Nodular & Low & Light & Black \\
\hline
\end{tabular}

The strains of Pyricularia oryzae Cav. pathogen can be divided into the following morphotypes (groups):

1. Strains with a unidirectional or concentric growth pattern, a felt structure of a conical relief and a low growth profile of olive-gray mycelium and a black substrate;

2. Strains with a zoned growth pattern, a flocky structure of nodular relief and a low growth profile of light gray mycelium and a black substrate; 
3. Strains with a unidirectional growth pattern, a felt structure of a uniform relief and a low growth profile of the mycelium of a typical gray color and a gray substrate;

4. Strains with multidirectional growth pattern, a flocky structure of conical relief and a low growth profile of the mycelium of a typical gray color and a brown substrate. 2020.

Figure 1 shows photographs of these Pyricularia oryzae Cav. morphotypes isolated in

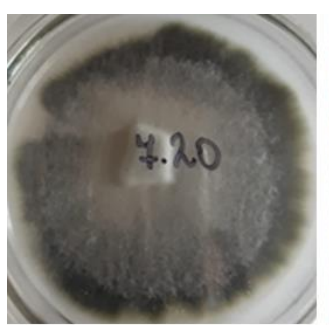

1

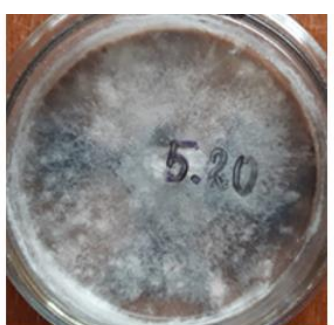

2

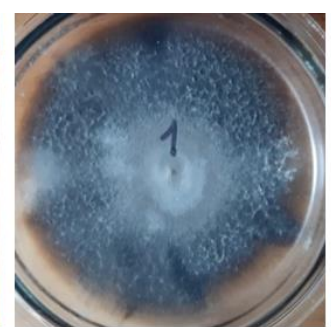

3

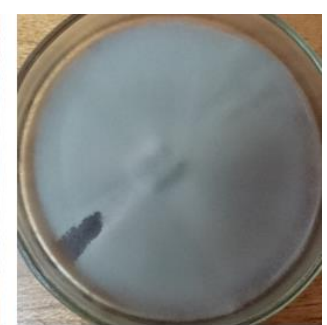

4

Fig. 1. Strains of blast agent Pyricularia oryzae Cav.

Note to Figure 1: the figure shows the cultures of the most characteristic representatives of the morphotype group (their characteristics are presented in Table 2).

This information was entered into the previously developed database "Strains of the Pyricularia oryzae Cav. pathogen in the south of Russia" [21], which contained factual material on the strains of the P. oryzae pathogen. These data can be used to analyze and monitor populations and pathotypes of the blast pathogen in the rice-growing regions of southern Russia. They presents the characteristics of the P. oryzae population by morphological and cultural traits, "morphological" and "DNA-passports" of the isolated strains of the blast pathogen from different ecological zones of rice cultivation in the south of Russia were compiled.

\subsection{Genetic certification of pathogen field strains using PCR (microsatellite) markers based on fragment analysis}

For the genetic classification of the Pyricularia oryzae Cav. strains found in Krasnodar region, we used the previously developed multi-primer PCR system [3, 17], which allowed simultaneous analysis of 6 microsatellite loci. This approach allows each DNA sample to be analyzed simultaneously for all six microsatellite loci. Amplification of each microsatellite locus is carried out with specific primers, one of which is labeled with a certain fluorescent dye (FAM, R6G, or ROX), which makes it possible to analyze PCR fragments separately using the corresponding detection channel.

The results of the analysis for microsatellite loci in duplicate are presented in Table 4.

Table 4. Classification of strains of Pyricularia oryzae Cav. causative agent of blast based on the obtained genetic profiles and their "DNA-passport".

\begin{tabular}{|c|c|c|c|c|c|c|}
\hline $\begin{array}{c}\text { Genotyp } \\
\mathbf{e}\end{array}$ & $\mathbf{A}$ & $\mathbf{B}$ & $\mathbf{C}$ & $\mathbf{D}$ & $\mathbf{E}$ & $\mathbf{F}$ \\
\cline { 2 - 7 } & $\mathbf{0 7 - 0 8}$ & $\mathbf{4 2 7 - 4 2 8}$ & $\mathbf{8 3 - 8 4}$ & $\mathbf{4 3 - 4 4}$ & $\mathbf{9 9 - 1 0 0}$ & $\mathbf{4 7 - 4 8}$ \\
\hline 1.1 & 137 & 172 & 177 & 209 & 186 & 220 \\
\hline 1.2 & 137 & 172 & 177 & 209 & 186 & 220 \\
\hline 5.1 & 137 & 172 & 180 & 205 & 211 & 220 \\
\hline 5.2 & 137 & 172 & 180 & 205 & 211 & 220 \\
\hline 7.1 & 139 & 172 & 180 & 203 & 211 & 220 \\
\hline 7.2 & 139 & 172 & 180 & 203 & 211 & 220 \\
\hline
\end{tabular}




\begin{tabular}{|c|c|c|c|c|c|c|}
\hline 10.1 & 139 & 172 & 180 & 203 & 211 & 220 \\
\hline 10.2 & 139 & 172 & 180 & 203 & 211 & 220 \\
\hline 11.1 & 137 & 172 & 180 & 203 & 211 & 220 \\
\hline 11.2 & 137 & 172 & 180 & 203 & 211 & 220 \\
\hline 12.1 & 137 & 172 & 180 & 203 & 211 & 218 \\
\hline 12.2 & 137 & 172 & 180 & 203 & 211 & 218 \\
\hline 13.1 & 139 & 172 & 180 & 203 & 211 & 220 \\
\hline 13.2 & 139 & 172 & 180 & 203 & 211 & 220 \\
\hline 16.1 & 139 & 172 & 180 & 203 & 211 & 220 \\
\hline 16.2 & 139 & 172 & 180 & 203 & 211 & 220 \\
\hline 20.1 & 137 & 172 & 180 & 203 & 211 & 220 \\
\hline 20.2 & 137 & 172 & 180 & 203 & 211 & 220 \\
\hline $\mathrm{K} 1-50$ & 129 & 174 & 177 & 219 & 217 & 222 \\
\hline $\mathrm{K} 2-31$ & 137 & 172 & 180 & 203 & 211 & 220 \\
\hline $\mathrm{K} 3-\mathrm{V}$ & 131 & 172,176 & 177 & 221 & 219 & 222 \\
\hline
\end{tabular}

Note to Table 4: blue - shows a fluorescent dye FAM; green - fluorescent dye R6G; red - fluorescent dye ROX; A, B, C, E, D, F - the designation of loci; numbers - the fragment length detected in each locus.

As a result of molecular genetic studies, 5 genotypes of the pathogen were identified. Their "DNA-passports" were compiled (Fig. 2, Table 5).

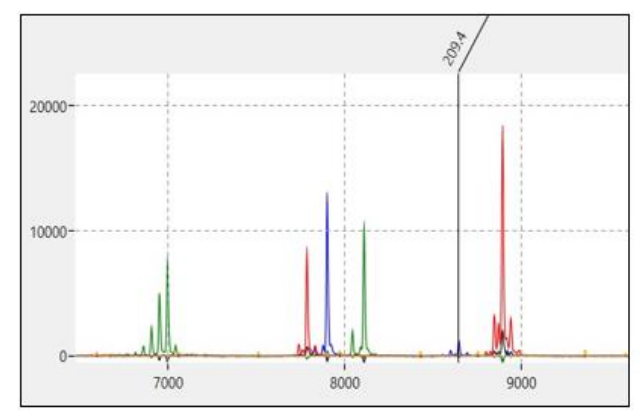

1

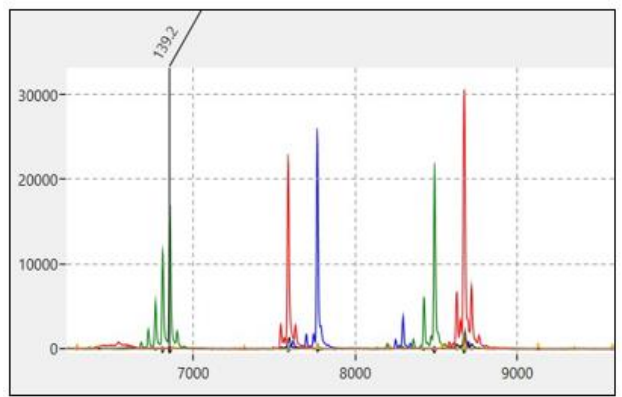

3

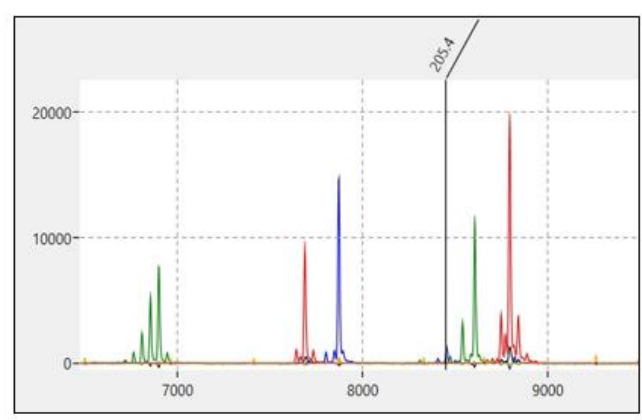

2

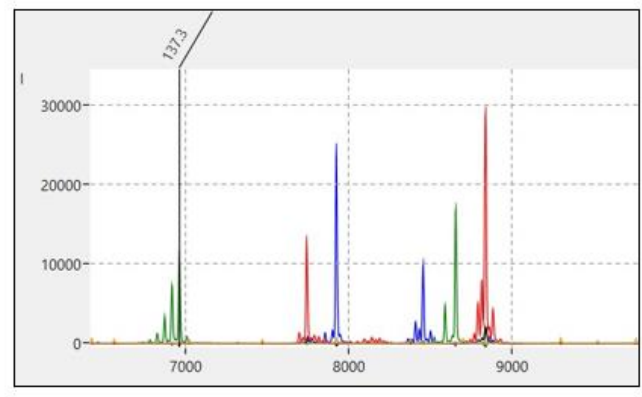

4

Fig. 2. Genetic profiles of the studied isolates of Pyricularia oryzae Cav., identified as a result of DNA analysis; 1 - genotype 1 (sample 1); 2 - genotype 2 (sample 5); 3 - genotype 3 (samples 7, 10 , 13, 16); 4 - genotype 4 (samples 11, 20, K2).

On the digitized genetic profiles of Pyricularia oryzae Cav. strains, each peak is a PCR fragment of a certain length. The color of the peak corresponds to the detection channel and determines the belonging of the fragment to one or another locus (Table 5). 
Table 5. Classification of strains of Pyricularia oryzae Cav. causative agent of blast based on the obtained genetic profiles.

\begin{tabular}{|c|c|c|c|c|c|c|c|}
\hline \multirow{2}{*}{ Genotype } & A & B & C & E & D & F & Sample \\
\cline { 2 - 7 } & $\mathbf{0 7 - 0 8}$ & $\mathbf{4 2 7 - 4 2 8}$ & $\mathbf{8 3 - 8 4}$ & $\mathbf{9 9 - 1 0 0}$ & $\mathbf{4 3 - 4 4}$ & $\mathbf{4 7 - 4 8}$ & \\
\hline 1 & 137 & 172 & 177 & 186 & 209 & 220 & 1.1 \\
\hline 2 & 137 & 172 & 180 & 211 & 205 & 220 & 5.20 \\
\hline 3 & 139 & 172 & 180 & 211 & 203 & 220 & $\begin{array}{c}7.20,10.20 \\
15.20,16.20\end{array}$ \\
\hline 4 & 137 & 172 & 180 & 211 & 203 & 220 & $\begin{array}{c}\text { K2, } 21.20, \\
20.20\end{array}$ \\
\hline 5 & 137 & 172 & 180 & 211 & 203 & 218 & 12.20 \\
\hline K1 & 129 & 174 & 177 & 217 & 219 & 222 & $50-2016$ \\
\hline K2 & 137 & 172 & 180 & 211 & 203 & 220 & $31-2016$ \\
\hline K3 & 131 & 172,176 & 177 & 219 & 221 & 222 & V-2016 \\
\hline
\end{tabular}

Among the studied strains, 5 variants of genotypes were identified. The genotype of samples 11 and 20 corresponded to the genotype of the previously studied strain 31 [17], which was used as a positive control.

Strain No. 1.20 was assigned to the first genotype; 5.20 - to the second, which had a unique genetic profile and morphotype. Strains No. 7.20, 10.20, 15.20, 16.20 from Krasnoarmeysky, Kalininsky and Slavyansky districts entered the third group and had the same DNA- profile. In strains No. 11.20, and 20.20, the genotype of the positive control K2 was revealed. They were assigned to the 4th genetic group. Strain sample No. 12.20 had a fifth genotype. This strain had a unique genetic profile and morphotype.

Thus, all obtained and studied strains of Pyricularia oryzae Cav. when describing by morphological and cultural characteristics, were divided into 6 morphotypes and, according to the results of DNA analysis, 5 genotypes of the pathogen were identified.

The obtained results were clustered using the Ward method [23] according to 12 characters (6 genetic characters and 6 morphological and cultural ones, Fig. 6).

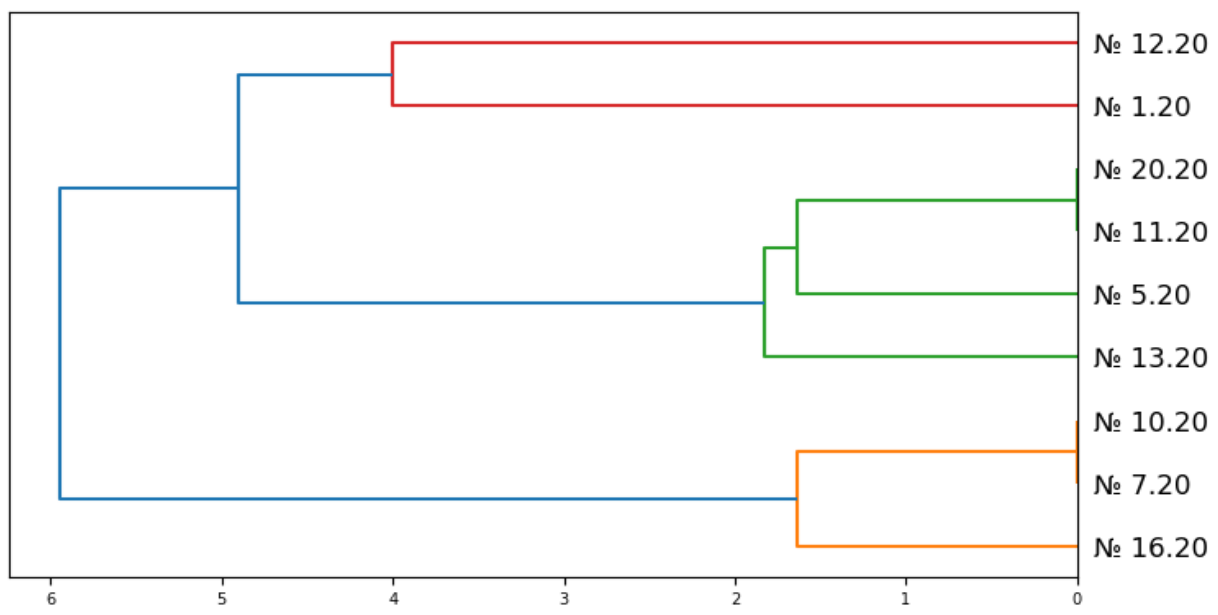

Fig.3. Clustering of P. oryzae Cav. strains by the Ward method. 
It can be seen from the figure that when a hierarchical dendrite is cut at a distance of 3 units (along the $\mathrm{x}$ axis), all studied strains are separated into 4 clusters with a unique genetic DNA- profile and morphotype. The first cluster included strain 12.20; the second - 1.20; the third: strains No. 20.20,11.20, 5.20 and 13.20; the fourth cluster included pathogen strains No. 10.20, 7.20, 16.20. These results are entered into the Database "Strains of Pyricularia oryzae Cav. pathogen, in south of Russia" [19] and can be used in phytopathological studies to control the variability of the pathogen.

\subsection{Determination of effective blast resistance genes in the south of Russia}

One of the goals of our work was to determine effective blast resistance genes [24], as well as genes for the virulence of Pyricularia oryzae Cav. pathogen. To achieve it, we have identified resistance genes of the fungus Pyricularia oryzae Cav. that are effective for southern Russia using the International Set of Differentiator Varieties of Pyricularia races obtained from the International Rice Research Institute (IRRI, Philippines) and the Institute of Agricultural Genetics (Hanoi, Vietnam). (Table 6): Pi-sh, Pi-b, Pi-z-5, Pi-z-t, Pi-5, Pi-1, Pi-7, Pi-kh, Pi-km, Pi-kp, Pi-ks, Pi-ta, Pi-ta2.

Table 6 shows the results of phytopathological testing for resistance to the Krasnodar population of the pathogen during artificial infection of rice differentiator varieties (Fig. 7).
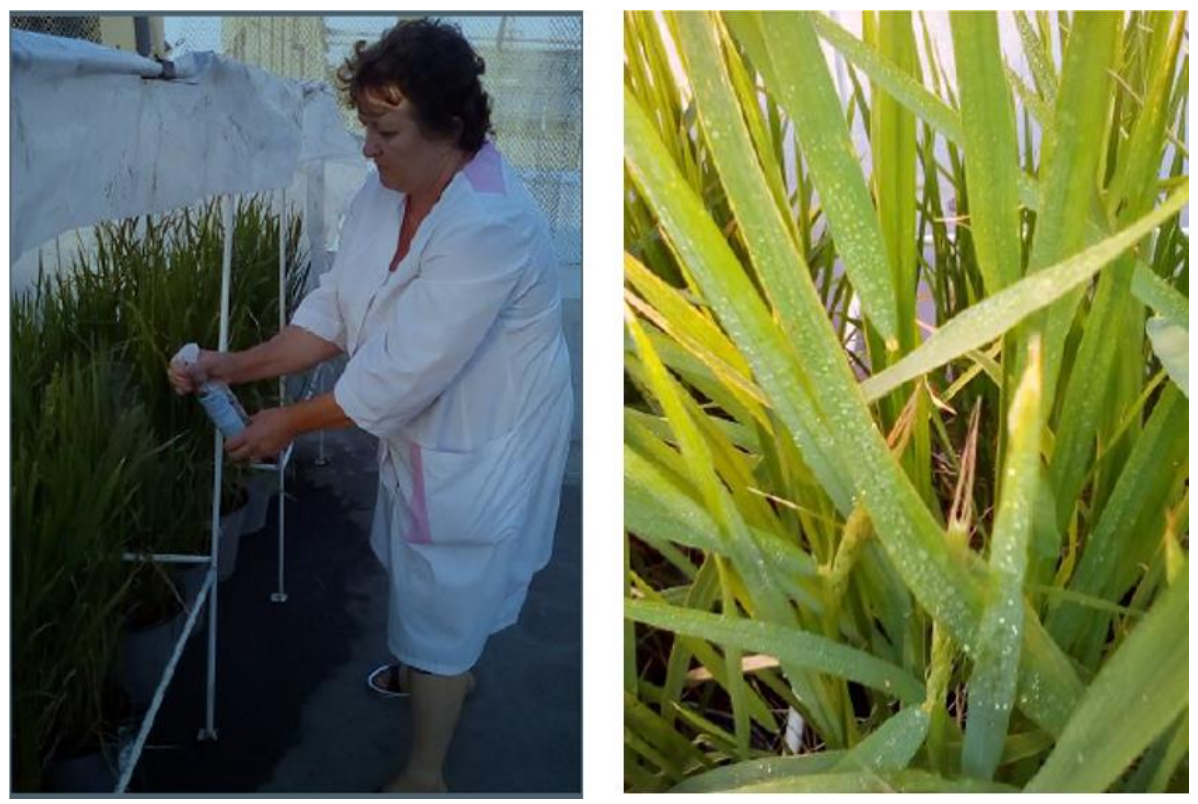

Fig. 4. Artificial infection of differentiating varieties with the phytopathogenic fungus P.oryzae Cav.

Table 6. Blast resistance of rice differentiator varieties with resistance genes (IDB laboratory, 2020).

\begin{tabular}{|c|c|c|c|c|c|}
\hline No & $\begin{array}{c}\text { Registration } \\
\text { number }\end{array}$ & Variety name & $\begin{array}{c}\text { Resistance } \\
\text { gene }\end{array}$ & $\begin{array}{c}\text { Variety } \\
\text { reaction }\end{array}$ & $\begin{array}{c}\text { Virulence } \\
\text { gene }\end{array}$ \\
\hline 1 & 11366 & Sha-tiao-tsao & $\boldsymbol{P i}$ - $\boldsymbol{k}$ s & $\mathrm{R}$ & \\
\hline 2 & 11367 & Ishikari-shiroke & $P i-\boldsymbol{i}$ & $\mathrm{S}$ & $\mathrm{Av}-\mathrm{i}+$ \\
\hline 3 & 11370 & Usen & $\boldsymbol{P i} \boldsymbol{a}$ & $\mathrm{R}$ & \\
\hline 4 & 11373 & Yaschiro-mochi & $P \boldsymbol{i}-t a$ & $\mathrm{~S}$ & $\mathrm{Av}-\mathrm{ta}+$ \\
\hline 5 & 11375 & Toride-1 & $P i-z t$ & $\mathrm{~S}$ & $\mathrm{Av-zt}+$ \\
\hline 6 & 11377 & Minehikari & $\boldsymbol{P i}-\boldsymbol{m}$ & $\mathrm{R}$ & \\
\hline
\end{tabular}




\begin{tabular}{|c|c|c|c|c|c|}
\hline 7 & 11382 & CO39 & No R gene & $\mathrm{S}$ & \\
\hline 8 & 11385 & IRBIK-KU [CO] & Pi-k & $\mathrm{R}$ & \\
\hline 9 & 11388 & IRBIKm-TS [CO] & $P i-k-m$ & $\mathrm{~S}$ & Av-k-m+ \\
\hline 10 & 11389 & $\begin{array}{c}\text { IRB1Kp-K60 } \\
{[\mathrm{CO}]}\end{array}$ & $P i-k-p$ & MS & \\
\hline 11 & 11390 & IRB11 - $\mathrm{La}[\mathrm{CO}]$ & $P i-1$ & $\mathrm{R}$ & \\
\hline 12 & 11391 & IRB17-M [CO] & $P i-7(t)$ & $\mathrm{R}$ & \\
\hline 13 & 11392 & IRB1 sh-Ku [CO] & $P i-s h$ & $\mathrm{~S}$ & Av-sh+ \\
\hline 14 & 11395 & IRB1 ta $-\mathrm{Ja}[\mathrm{CO}]$ & $P i-t a$ & $\mathrm{R}$ & \\
\hline 15 & 11396 & $\begin{array}{c}\text { IRBl ta - ME } \\
{[\mathrm{CO}]}\end{array}$ & $P i-t a$ & MS & \\
\hline 16 & 11399 & $\begin{array}{c}\text { IRB1 ta2 - IR64 } \\
{[\mathrm{CO}]}\end{array}$ & $P i-t a 2$ & $\mathrm{~S}$ & Av-ta2+ \\
\hline 17 & 11400 & Pi-z5 & $S$ & Av-z5+ & \\
\hline 18 & 11405 & IRB19 - W [LT] & $P i-9$ & $\mathrm{~S}$ & Av-9+ \\
\hline 19 & 11406 & $\begin{array}{c}\mathrm{IRB} 13-\mathrm{CP} 4 \\
{[\mathrm{LT}]}\end{array}$ & $P i-3$ & $\mathrm{~S}$ & Av-3+ \\
\hline 20 & 11409 & IRB1 K3 [LT] & $P i-k h$ & $\mathrm{~S}$ & Av-kh+ \\
\hline 21 & 11431 & IRBl -Fu & $\mathrm{Pi}-\mathrm{z}$ & $\mathrm{R}$ & \\
\hline 22 & 11433 & IRBl zt-T & $P i-z t$ & $\mathrm{~S}$ & $\mathrm{Av}-\mathrm{zt}+$ \\
\hline 23 & 11436 & IRBL b-B & Pi-b & $\mathrm{R}$ & \\
\hline 24 & 11437 & IRBlt- K59 & Pi-t & $\mathrm{S}$ & Av-t+ \\
\hline 25 & 11445 & IRB112 - M & Pi-12(t) & $\mathrm{R}$ & \\
\hline 26 & 11446 & IRB119 - A & Pi-19 & $\mathrm{S}$ & Av-19+ \\
\hline 27 & 11451 & IRB111-Zh & $\operatorname{Pi-11}(\mathrm{t})$ & $\mathrm{R}$ & \\
\hline 28 & $\mathrm{St}$ & Novator & $\mathrm{S}$ & & \\
\hline 29 & - & Sonet & $\mathrm{R}$ & & \\
\hline
\end{tabular}

The effective blast resistance genes identified in this work are recommended for use in breeding programs for the development of disease-resistant rice varieties in rice-growing zones of southern Russia [24].

\section{Discussion}

The use of molecular markers is a new, developing science. At the present time, it will spread to all types of agricultural animals, plants and microorganisms.

In this work, we have demonstrated the possibilities of using molecular marking technologies in the study of biodiversity of the most dangerous pathogen in all areas of the world rice cultivation, Pyricularia oryzae Cav.

Introduced genotyping of strains of the pathogen P.oryzae Cav. allowed to create their genetic morphological and "ДНК-passport", which were entered into the database "Strains of the patogen Pyricularia oryzae Cav. south of Russia [21]. It represents a collection of data reflecting information on the biodiversity of phytopathogenic fungi and specimens of Pyricularia oryzae Cav strains isolated from herbarium material with signs of harmlessness to the crop.

This will allow in the future to carry out a comparative characteristic of the microsatellite profile outside the selected field strain of the pathogen P. monitor the variability of the fungus and predict the spread of the disease.

Identified genes for resistance to blast infection to the Krasnodar population of the pathogen P. oryzae Cav. recommended for use in breeding programs for the creation of disease-resistant rice varieties in the rice-growing areas of the south of Russia.Thus, the strategy of applying new methods of DNA marking is based on the reliability, efficiency, information and interoperability of the above approaches. Knowledge of the interaction 
between the pathogen and the plant-host will allow, over time, to switch to intensive farming, to produce plants and animals with greater productivity and more resistant to various environmental factors.

\section{Conclusions}

Based on molecular genetic approaches, a study of the biodiversity of the phytopathogenic fungus Pyricularia oryzae Cav. was carried out in the south of Russia, the classification of morphological and cultural traits of the pathogen was carried out.

In 2020, monitoring was carried out and 9 strains of the pathogen were isolated from the affected herbarium material collected from the fields of five ecological rice-growing zones of Krasnodar region (Krasnoarmeisky, Kalininsky, Abinsky, Slavyansky districts, Krasnodar).

Using a multiplex PCR system based on fragment analysis, among the studied strains of Pyricularia oryzae Cav. 5 genotypes were identified in 2020, each of which is was characterized by a unique genetic profile. Their "DNA- passports" have been compiled.

The studied isolates of the blast pathogen were characterized by morphological and cultural traits. 6 morphotypes of the pathogen were identified.

Classification of the pathogen by morphological, cultural and genetic traits will allow obtaining scientifically grounded and comparable data that can be used in the analysis of the interaction of blast strains with rice plants on different varieties and in different agrotechnological conditions in order to improve and rationalize agricultural activities. In addition, the studied approaches open up the possibility of using data in breeding, allowing the identification of pathogen forms that infect certain varieties.

The research was carried out with the financial support of the Kuban science Foundation in the framework of the scientific project № 20.1/3.

\section{References}

1. V.I. Terekhov (Moscow, «Agropromizdat», 1989)

2. V.P. Sokirko, V.S. Gorkovenko, M.I. Zazimko, Phytopathogenic fungi (Krasnodar, 2014)

3. E.V. Dubina, M.G. Ruban, Yu.V. Aniskina, Achievements of science and technology of the agro-industrial complex 10, 32 (2018)

4. V.G. Anikeev (abstract of Ph.D. in biology thesis, Moscow, 1990)

5. E.V. Dubina, P.I. Kostylev, M.G. Ruban, Aniskina Yu.V., Shilov I.A., Velishaeva N.S., Esaulova L.V., Grain economy of Russia, 6, 54 (2017)

6. P.I. Kostylev, E.V. Krasnova, A.A. Redkin, E.V. Dubina, J.M. Mukhina, Ecological genetics 15, 3 (2017)

7. G.L. Zelensky (Krasnodar, KubSAU, 2016)

8. E.V. Dubina, Z.M. Mukhina, E.M. Kharitonov, V.N. Shilovskiy, E.S. Kharchenko, L.V. Esaulova, N.N. Korkina, E.P. Maximenko, I.B. Nikitina, Rus. J. of Genetics 51, 8 (2015)

9. M. G. Murray. Rapid isolation of high molecular weight plant DNA, Genomt, 40 (1980)

10. S.N. Ahn, Y.-K. Kim, H.-C. Hong, S.-S. Han, S.-J. Kwon, H.- C. Choi, H.-P.Moon, S. R. McCouch, Euphytica, 116, 1 (2000) 
11. H. Adreit, D. Santoso, D.W. Utami, J. L. Notteghem, M. H. Lebrun, D. Tharreau, Molecular Ecology Notes, 7 (2007)

12. E. D. Kovalenko, Yu.V. Gorbunova, A.A. Kovaleva, Methodological guidelines for assessing the resistance of rice varieties to blast causative agent et al. (Moscow, 1988)

13. Guidelines for the identification, accounting and methods of developing measures to combat rice diseases (Krasnodar, ARRRI, 1981)

14. I.A. Kostenko (Abstract of Ph.D. in biology thesis, Krasnodar, 2006)

15. E.R. Gritskevich, I.E. Buchenkov, N.V. Ikonnikova, Laboratory workshop on microbiology (Minsk, 2017)

16. V.D. Poliksenova, A.K. Khramtsov, S.G. Piskun, Biology (Minsk, 2004)

17. E.V. Dubina, A.V. Alabushev, P.I. Kostylev, Physiol. Mol. Biol. Plants, 26 (2020)

18. E.V. Dubina, M.G. Ruban, Yu.V. Aniskina, Rice growing 44, 3 (2019)

19. E.V. Dubina, S.V. Garkusha, M.G. Ruban, L.V. Esaulova, E.R. Avakyan, I. V. Baluster, Science of the Kuban (2017)

20. E.V. Dubina, E.S. Kharchenko, L.I. Seraya et al. Certificate for the Database «Strains of Pyricularia oryzae Cav. pathogen, south of Russia» (2019)

21. D. Nartymov, E. Kharitonov, E. Dubina, S. Garkusha, M. Ruban, N. Istomin, P. Kostylev, Microbiol. Res., 12, 3 (2021)

22. J.H. Ward, J. of Amer. Stat. Ass., 58 (1963)

23. Y.-C. Cho, S.-W. Kwon, I.-S. Choi, J. of Cr. Scien. and Biotech, 10, 4 (2010)

24. E.V. Dubina, E.S. Kharchenko, L.I. Seraya et al., Certificate on the Database «Analysis of the populations of rice blast (Pyricularia oryzae Cav.) causative agent on the basis of virulence» (2019) 